\title{
Curtailing Academic Dishonesty Using Student Affairs Personnel: The Case of a Private Faith-Based Higher Institution, South-West Nigeria
}

\author{
Dare Ojo, Omonijo
}

College of Science and Technology, Covenant University, P. M. B. 1023, Ota, South-West Nigeria.

Email: oluwadare.omonijo@covenantuniversity.edu.ng.

\section{Olumuyiwa Akinrole, Oludayo}

Department of Business Management, Covenant University, P. M. B. 1023, Ota, South-West Nigeria.

\section{Onyekwere Oliver Chizaram, Uche}

Department of Religion and Human Relations, Nnamdi Azikiwe University,Awka, Anambra-State, South-East Nigeria

\author{
Omolola Abidemi, Rotimi \\ Department of Psychology, Covenant University, Ogun-State, \\ P. M. B. 1023, Ota, South-West Nigeria.
}

Doi:10.5901/mjss.2014.v5n23p1504

\begin{abstract}
This study explored the usefulness of Student Affairs Personnel in ensuring academic honesty in a private Faith-Based higher institution, South-West Nigeria, between 2011 and 2014. Using data from descriptive source, the study investigated categories of academic dishonesty and the number of students involved. Moreover, it examined gender composition of these students and disciplinary action given to them. Furthermore, it tried to find out measures which Student Affairs Personnel used to ensure academic integrity and their effectiveness. Relying on raw data retrieved from records, the study came up with nine categories of academic dishonesty that involved ninety-nine students, out of which male students represent the majority (61.6\%) while their female counterparts represent the minority (38.4\%). The result indicated ten measures which Student Affairs Personnel engage in curtailing academic dishonesty. Nevertheless students in the sample, based on questionnaires distributed, submitted that these Personnel were effective in nine out of ten measures. Finally, the study revealed expulsion as disciplinary action placed on culprits.
\end{abstract}

Keywords: Student Affairs Personnel; curtailing; academic dishonesty.

\section{Introduction}

Previous studies attest to the alarming rate of academic dishonesty at all levels of education in developed and developing societies (Amie et al., 2013). While a considerable amount of research has been carried out on this subject in Nigeria Babalola, (2012), there remains a critical need for further studies on the usefulness of Student Affairs Personnel, which has hitherto been scarcely discussed in literature. Although a similar study was conducted by Akinnubi \& Kayode, (2012) but it failed to consider the usefulness of Students' Affairs Personnel in ensuring academic integrity, which is largely needed to ensure quality education in Nigeria today. Therefore, the thrust of this paper is to extend previous researches to add a significant value of Student Affairs Personnel in literature in order to fill this gap in knowledge.

The importance of this effort is hinged on the failed value system in the Nigerian polity, which explains why dishonest behaviours have coined acceptance as the norm (Nnonyelu et al., 2013). The challenge of lack of academic integrity in the public universities was pivotal to the establishment of private universities (Aina, 2010). The Student Affairs Department in the new private universities is now redesigned and saddled with the responsibility of moulding students' character (Covenant University 2014).

Most secondary school students, who transit into higher institutions of learning in Nigeria have been negatively 
influenced (Otokunefor, 2011). Hence, there is a need for a renewed of the mindset of these students using the staff of Student Affairs Department. The fact that this effort has never been explored in tackling the lingering problem of academic dishonesty could make this study very significant from the perspective of a private sector higher education in Nigeria.

\section{Objectives of the Study}

This paper is set to achieve the following objectives:

1. To investigate the categories of academic dishonesty.

2. To investigate the number of students involved in academic dishonesty.

3. To determine gender composition of students involved in academic dishonesty.

4. To investigate disciplinary actions taken against the perpetrators of academic dishonesty.

5. To discover measures which Student Affairs Personnel engaged to curtail academic dishonesty.

6. To find out if Student Affairs Personnel are effective in enforcing these measures.

\section{Operational Definition of Terms.}

The following terms are used in this article as defined below:

a. Curtailing Academic Dishonesty-Reducing cheating in academia.

b. Academic dishonesty-behaviours that contravene rules and regulations guiding the conduct of examinations

c. Categories of Academic Dishonesty-Different ways of perpetuating academic dishonesty

d. Strategies for Curtailing Academic Dishonesty- Measures put in place to ensuring academic integrity.

e. Usefulness of Student Affairs Personnel-Duties of Student Affairs Staff.

f. Academic Integrity- Total compliance with the rules and regulations of examinations

\section{Literature Review}

\subsection{Categories of Academic Dishonesty}

Different categories of academic dishonesty pervade literature in academia (Eastman et al., 2008). Prominent among them is plagiarism, which Fawkner \& Keremidchieva, (2004) perceive as using another person's work without due acknowledgement. This practice is common among lazy students and scholars, who do not have capacity to conduct research on their own accord. However, the practice is not limited to students and lecturers, journalists and politicians are equally involved (Morriso, 2013; Ungar, 2014).

Apart from the above, another popular form of academic dishonesty is fabrication, which Adeyemi, (2010) views as making up data through authorized or unauthorized access and presenting them as pure. In most institutions, it manifests in alteration of grades in any academic assessment. Premium Times (2014) claims that fabrication includes: (i) changing answer scripts in order to negotiate for a higher grade or copying answers from another student, (ii) cribbing, which means the use of prohibited materials, information, or study aids in an academic exercise and (iii) substitution which means utilizing a proxy in any academic exercise.

Based on the work of Archibong, (2012), intimidation is another form academic dishonesty prominent among students. It involves candidates or their accomplices engaging in an act aimed at striking fear, either verbal or physical or mental attack, in the heart of examination officials. However, the most dangerous among the three is mental attack because it involves exposing a weapon (gun) to invigilators warning them the danger of not cooperating with them. Denga \& Denga, (1998) highlighted other forms of academic dishonesty which include networking, macro-chips, collusion, ECOMOG etc. Most students used to smuggle these materials into the examination halls through their pants, bra and pockets.

Scholars such as Kobiowu \& Alao, (2005) see obstruction as another cogent category of academic dishonesty among students. Dwelling on these authors, obstruction is viewed as "any scheme aimed at impeding detection of examination malpractice". It is a design of corrupt school officials to use classrooms instead of a hall in the conduct of public examinations. By this design, a supervisor will be moving from one room to other, giving invigilators who want to commit fraud latitude to do so when he is not in their room.

Although views of the above authors are relevant to this discourse, but it could be observed that none of them mentioned leakage of examination papers in their studies. Thus, Chigozie, (2012) perceives leakage as an unauthorized 
access of certain persons to the contents of question papers prior examination. It has been observed that this type of academic dishonesty is very devastating to the credibility of examination body because the menace is always exposed to the entire populace. Also, it makes the entire public to doubt the integrity of personnel in institutions where leakages occur. Besides, it prompts the public to react against their operations as recorded in West Africa Examination Council of 1963, 1967, 1970 etc (Oluyeba, 1998).

However, the above scholars should be commended for their contributions to knowledge on different forms of academic dishonesty, but it could be observed that these authors focused on the categories of academic dishonesty in the public sector higher institutions and neglected the private sector. This study intends to address this flaw this gap and also suggests a comparative study of the categories of academic dishonesty between the public and private sector higher education in Nigeria.

\subsection{Factors Responsible for the Endemic Nature of Academic Dishonesty in Academia in Nigeria.}

Increasing emphasis on success through perversion seems to have become an integral part of life in modern societies. Currently, the rate of its escalation in countries of the world is worrisome (Maurer, 2013). However, it emergence and escalation in Africa, Kroll Study of Fraud (2012) that was largely known for probity and integrity prior colonialism is a surprise to well-meaning persons in the continent. The case of sub-Saharan Africa countries is an issue of concern in academia because the region, according to Theron, (2013) has retained unenviable distinction in perpetuating fraud worldwide. The problem is escalating in Nigeria at an alarming dimension and it is largely associated with the short cut syndrome which many people perceived as the best way of achieving success.

Many reasons have been advanced for the escalation of academic dishonesty in the country. Prominent among them is lack of seriousness of the elite class in reducing the scourge to the barest minimum. Omonijo \& Fadugba, (2011) shed more on this critical issue. Using the data of 545 respondents, these scholars examined reasons why the Nigerian government failed to implement all laws on examination misconduct. Findings of their survey pointed to the involvement of the children of government functionaries, which represented the absolute majority of the sample (24. 95\%). This was followed by lack of seriousness of the government officials' with $10.01 \%$, while $8.99 \%$ other respondents associated it with moral problem of government functionaries. This brings to bear the problem of leadership in Nigeria.

Omonijo et al., (2011b) likened leadership with an engine that propels countries to either advancement or backwardness. Countries with good leadership tend to advance in all spheres of life, while Omonijo, (2008) claims that societies with poor leadership are doomed. Several past articles have attributed the majority of evils hindering the development of Nigeria to her poor leadership (Igwe, 2011). Since her political independence in 1960, Nigeria has been under the control of bad leaders, who encouraged dishonesty practices Igwe (2011) not only in academia, but also in all spheres of life.

Improper child upbringing in many homes in Nigeria today is another cogent contributing factor. Adequate training given to children at home in the past does not exist in Nigeria any more, which explains why antisocial behaviours are spreading at alarming proportion (Rotimi et al., 2014). Specifically, (Omonijo, 1995; Animasahun, 2014) attribute this problem to marital conflict among couples, broken homes and single parenthood. In recent times, most children are not trained due to the factors raised by these scholars. In such a situation, there is every tendency for children to develop antisocial behaviours. Although it is evident in literature that children from good homes often develop antisocial behaviours, but such could be associated with peer group influence outside the family. It shows that those children were trained at home but they did not comply. They are called 'akoigba' meaning children who refused training at home.

Such children are many in the present day Nigeria because inordinate desire for money is prevalent among many parents and it prompts them to neglect their social responsibilities in the family. Children from such homes are left with house girls or boys, who themselves don't know what it takes to train children. This type of children have unlimited access to television, video, computer games, satellite dish etc. The implication is that they copy what they watch in these gadgets. Children in this category are called 'abiiko' meaning lack of home training. Such children are many in Nigeria today and they constitute nuisance to the peace and tranquility of the society. In other words, lack of parental involvement in children training can have long-lasting negative effects on them. Children who don't have a close relationship with their parents are at risk of teen pregnancy, more likely to drink alcohol or smoke cigarettes, and more likely to live a sedentary life (Drinkworth, 2014). They are also more likely to withdraw from school or suffer from depression.

In Yoruba-land, Western Nigeria, in early 60s and 70s, many children were afraid of indulging in bad behaviours because they valued their parents' names. This brings to bear the popular adage reigning at that point in time, which include 'Orukorere sanjuwura atifadaka,' meaning a good name is better than silver and gold, 'ranti omo eniti iwo nse' meaning remember the son of whom you are. These popular cultural adages are no longer in vogue in recent times. It is 
unfortunate to hear many children today, saying to hell with father's name. What matters to such children is money, irrespective of its source.

Scholars such as Brimble and Stevenso-Clarke, (2005) believe that parental indiscipline and abuse of wealth have been sustaining the phenomenon of academic dishonesty. Many parents as noted above are bad examples to their children. Dwelling on Drinkworth, (2014) unhealthful behaviours of parents have higher negative effects on their children. According to this author, a child of an alcoholic parent is four times more likely to become an alcoholic. Most parents believe that money can be used to influence success for their children, even if it involves bribery (Gallegos 2014), which confirms the submission of Omonijo \& Fadugba, (2011) on this discourse.

\subsection{The Usefulness of Student Affairs Personnel in Nigerian Higher Education.}

In Nigeria, the usefulness of Student Affairs Staff in moulding students' character has not been fully explored in literature, since inception of higher education in 1934. In most of the existing public tertiary institutions, Student Affairs Department exists in vacuum. Apart from few roles, such as, hostel accommodation Bassey, (2001), income support -bursary award, when necessary Akpan, (2000), which the department is known for, students who are not in need of these services may not feel the impact of the Department throughout their studentship on campus. Although, Johnson (1998) noted that Student Personnel Services in the University of Ilorin include: psychological services, school social services, health services, attendance services and guidance services but it could be observed that these services have not been thoroughly pursued by the Student Affairs Personnel in higher education. Thus, literature in support of the above deficiency and other vital activities geared towards students' development; mostly in areas of character transformation in tertiary institutions is very scanty. Although the management of private sector higher education has been intensifying endeavours to enforce effective measures in ensuring character transformation among students, but such efforts have been ignored in literature. Therefore, this study is conducted to address this gap in knowledge.

\section{Theoretical Standpoint}

Academic dishonesty could be regarded as a product of social interaction, because most of its cases are being perpetuated in the process of interaction. It is on this ground that this paper considers Social Control Theory as a platform for explaining the topic under study. The paradigm is rooted in measures relating to socialization, which can be used to ensure academic integrity.

It was developed by (Nye, 1958), who proposes that exploiting the process of Socialization and Social Learning builds self-control and reduces the inclination to indulge in antisocial behaviours. The author derives his work from functionalist theories of crime and argues that antisocial behaviours of students can be controlled in the following four ways:

\subsection{Direct Control}

This measure emphasizes punishment for any violation and rewards for compliance with the existing rules and regulations. This viewpoint goes to confirm the idea of Gallegos, (2014) who claims that disobedient children should be disciplined while the obedient children should be rewarded. Nye, (1958) advocates these methods for parents at home, authorities in institutions of learning and superiors in work-settings.

\subsection{Internal Control}

This measure deals with refraining from delinquency through the conscience or superego. Dwelling on Nye, (1958) people can only function constructively in the society, if they acquire a system of values, norms, ethics, and attitudes which are reasonably compatible with that society. These variables are acquired through the process of "socialization," and structural model of psychoanalysis, developed through the formation of a superego (Friedman and Schustack, 2011). In view of the above authors, superego is the last major system of personality to be developed and it represents an internalized version of society's norms and standards of behaviours (Silberman, 2012). In Freud's (1940) view, the human organism is not born with a superego; rather, children must incorporate it through interactions with parents, teachers, and other 'formative" figures in the society. Hence, it is the incorporation of superego acquired in the process of socialization that makes children to abstain from deviant behaviours. 


\subsection{Indirect Control}

This measure means reducing criminal activities by identifying with those who influence behaviours, probably role models, godfathers, teachers, staff, mentors etc in order to comply with societal norms, rules and regulations. Nye, (1958) believes that if children are caught in delinquent acts, it might cause pain and disappointment to parents and others with whom they are closely associated with. In order to avoid denting these persons image, children tend to behave well.

\subsection{Control Through Needs Satisfaction}

This strategy means curtailing criminal activities of the youths by meeting their needs. Therefore, it is assumed that if children are adequately catered for, they may not indulge in anti-social behaviours.

Based on the foregoing, social control theory proposes that people's relationships, commitments to values, norms, and beliefs encourage compliance to the rules and regulations. Thus, Nye (1958) concludes that if moral codes are internalized and individuals are tied into it, and have a stake in their wider community, they will voluntarily limit their propensity to criminality.

Given the above, the lingering problem of academic dishonesty in Nigerian education system could be reduced drastically, but such measures or strategies have never been given any priority in higher education. Hence, effectiveness of Student Affairs Personnel in enforcing these measures has never been ascertained in literature. Thus, this study intends to correct this gap in knowledge.

\section{Methods}

\subsection{Research Design and Instrument}

This study employed a survey research and ex-posit descriptive designs. A structured questionnaire was used to collect information from the respondents. The likert scale was the pattern used in determining the responses from the sampled respondents.

\subsection{Population, Sample Size and Sampling Techniques}

The total number of students that make up the population of this study is 5,123 . The sample size was determined by using both the stratified sampling technique in the first instance and the proportional allocation techniques afterwards. The sample size used in this study is 204 which represent all the 20 Departments of the university

\subsection{Data Validity and Reliability}

This study employs construct validity of instrument, which entails the use of a panel of experts familiar with issues being investigated. Their comments and suggestions were incorporated into the study. Also, 50 questionnaires were preadministered to Students Leaders and Senior Officers in the Department of Student Affairs. Their judgments reflected what was finally obtained from the entire sample.

\subsection{Data Analysis}

Simple percentage was used to analyse the data collected for this study. This involves frequency table and percentage. Also, figures and chart were used for proper clarification where necessary.

Table 1: Response Rate of Respondents

\begin{tabular}{|c|c|c|c|c|}
\hline SN & \multicolumn{2}{|c|}{ Distributed Questionnaires } & \multicolumn{2}{c|}{ Returned Questionnaires } \\
\hline 1 & Male & Female & Male & Female \\
2 & 130 & 130 & $101(49.5 \%)$ & $103(50.5 \%)$ \\
\hline Total & \multicolumn{2}{|c|}{260} & \multicolumn{2}{c|}{$\mathbf{2 0 4}(\mathbf{7 8 . 5} \%)$} \\
\hline
\end{tabular}

Source: Field work 2014. 
As indicated in table 1, 260 questionnaires were distributed to respondents but 204 (78.5\%) was returned to the researchers. Out of this figure, 103 (50.5\%) were female while the remaining 101(49.5\%) were male.

\subsection{Results}

Objectives 1 investigated categories of academic dishonesty recorded within the period under study. The Results of investigation is presented in table 2 below:

Table 2: Categories of Academic Dishonesty.

\begin{tabular}{|c|c|c|c|c|c|}
\hline \multirow[t]{2}{*}{ SN } & \multirow[t]{2}{*}{ Categories } & \multicolumn{4}{|c|}{ Year } \\
\hline & & 2011 & 2012 & 2013 & 2014 \\
\hline \multirow{2}{*}{$\begin{array}{l}1 \\
2\end{array}$} & The use of calculator & The use of & The use of I-Pod & Copying from others. & \multirow{7}{*}{$\begin{array}{l}\text { The use of I-Pod } \\
\text { Copying from } \\
\text { others. } \\
\text { Copying for a } \\
\text { piece of paper } \\
\text { (microchip). } \\
\text { Exchanging } \\
\text { answer scripts. } \\
\text { Forging of marks. }\end{array}$} \\
\hline & The use of mobile & $\begin{array}{l}\text { calculator. } \\
\text { The use of mobile }\end{array}$ & Copying from & Copying from a piece & \\
\hline 3 & The use of I-Pod & \multirow{6}{*}{$\begin{array}{l}\text { phone. } \\
\text { The use of I-Pod } \\
\text { Copying from } \\
\text { others. } \\
\text { Copying from a } \\
\text { piece of paper } \\
\text { (microchip). } \\
\text { Exchanging answer } \\
\text { scripts. }\end{array}$} & \multirow{5}{*}{$\begin{array}{l}\text { Copying for a piece } \\
\text { of paper } \\
\text { (microchip). } \\
\text { Exchanging answer } \\
\text { scripts. } \\
\text { Buying of question } \\
\text { papers. }\end{array}$} & Exchanging answer & \\
\hline 4 & Copying from others & & & scripts. & \\
\hline 5 & $\begin{array}{l}\text { Copying from a piece } \\
\text { of paper (microchip) }\end{array}$ & & & $\begin{array}{l}\text { Leakage of } \\
\text { examination questions. }\end{array}$ & \\
\hline 6 & $\begin{array}{l}\text { Exchanging answer } \\
\text { scripts }\end{array}$ & & & & \\
\hline 7 & Buying of question & & & & \\
\hline 8 & $\begin{array}{l}\text { papers } \\
\text { Leakage of }\end{array}$ & & & & \\
\hline 9 & $\begin{array}{l}\text { examination } \\
\text { questions } \\
\text { Forging of marks }\end{array}$ & & & & \\
\hline Total & 9 & 6 & 5 & 4 & 5 \\
\hline
\end{tabular}

Note: The period of study was between 2010/2011 and 2013/2014 academic year.

Source: Field Work, 2014

Deducing from table 2 above, nine categories of academic dishonesty were discovered between 2011 and 2014. Out of this figure, 6 categories were recorded in 2011 while 5 categories were recorded in 2012. In 2013 and 2014, 4 and 5 categories were recorded respectively. The highest category was recorded in 2011 followed by 2012 and 2014. This is further analyzed in a form of histogram as represented in figure i below:

Figure i: Categories of Academic Dishonesty

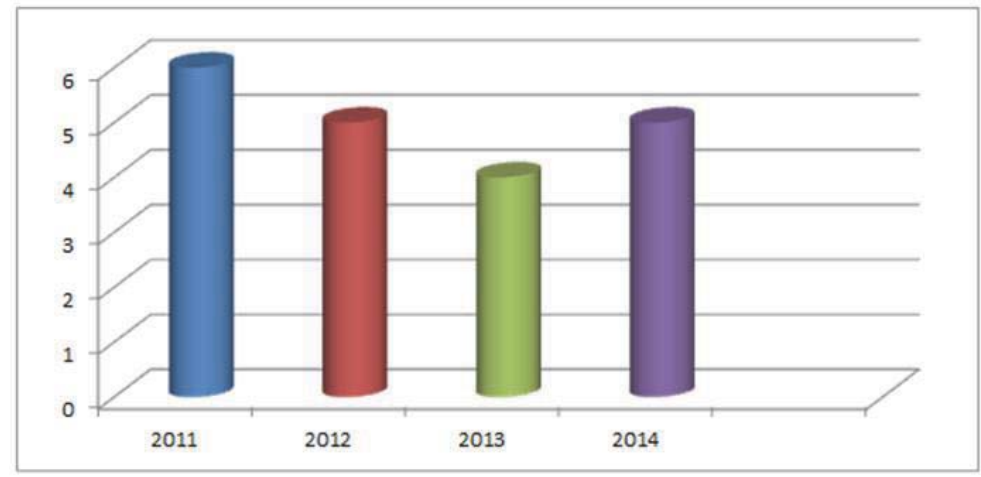

Source: Field Work, 2014

Objective ii of this study investigated the number of students caught for academic dishonesty. The result is presented in table 3 below: 
Table 3: Number, Gender Composition and Disciplinary Measures Given to Students Who Indulged in Academic Dishonesty.

\begin{tabular}{|c|c|c|c|c|c|c|c|c|c|c|c|c|}
\hline \multirow[t]{3}{*}{$\mathbf{S N}$} & \multirow{2}{*}{$\begin{array}{l}\text { Categories of } \\
\text { Academic Dishonesty }\end{array}$} & \multicolumn{2}{|c|}{$\begin{array}{l}2011 \\
\text { Gender }\end{array}$} & \multicolumn{2}{|c|}{$\begin{array}{l}2012 \\
\text { Gender }\end{array}$} & \multicolumn{2}{|c|}{$\begin{array}{l}2013 \\
\text { Gender }\end{array}$} & \multicolumn{2}{|c|}{$\begin{array}{l}2014 \\
\text { Gender }\end{array}$} & \multicolumn{2}{|c|}{ Total (\%) } & \multirow{2}{*}{$\begin{array}{l}\text { Disciplinary } \\
\text { Actions }\end{array}$} \\
\hline & & & & & & & & & & & & \\
\hline & & $M$ & rit & M & er & $\mathrm{M}$ & $\bar{F}$ & M & ter & M & detr & \\
\hline 1 & The use of calculator & & $04(4.0 \%)$ & & & & & & & & $04(4.0 \%)$ & Expulsion \\
\hline 2 & The use of mobile & $01(1 \%)$ & - & - & - & - & - & - & - & $01(1 \%)$ & - & Expulsion \\
\hline 3 & $\begin{array}{l}\text { phone.e of I-Pod. } \\
\text { The use of }\end{array}$ & $02(2 \%)$ & & $01(1 \%)$ & - & & & $02(2 \%)$ & - & $05(5.1 \%)$ & & Expulsion \\
\hline 4 & Copying from others. & $04(4.0 \%)$ & $05(5.1 \%)$ & $02(2 \%)$ & & $03(3 \%)$ & $05(5.1 \%)$ & $03(3.0 \%)$ & & $12(12.1 \%)$ & $10(10.1 \%)$ & Expulsion \\
\hline 5 & Copying from a piece & $6(6.1 \%)$ & $5(5.1 \%)$ & $05(5.1 \%)$ & $04(4.0 \%)$ & $02(2 \%)$ & $05(5.1 \%)$ & $05(5.1 \%)$ & $4(4.0 \%)$ & $18(18.2 \%)$ & $18(18.2 \%)$ & Expulsion \\
\hline 6 & Exchanging answer & $5(5.1 \%)$ & $3(3.0 \%)$ & $02(2 \%)$ & - & $02(2 \%)$ & $02(2 \%)$ & $03(3.0 \%)$ & $1(1 \%)$ & $12(12.1 \%)$ & $6(6.1 \%)$ & Expulsion \\
\hline 7 & Buying of question & - & - & $06(6.1 \%)$ & - & - & - & - & - & $06(6.1 \%)$ & - & Expulsion \\
\hline 8 & $\begin{array}{l}\text { papers. } \\
\text { Leakage of }\end{array}$ & - & - & - & - & $06(6.1 \%)$ & - & - & - & $06(6.1 \%)$ & - & Expulsion \\
\hline 9 & $\begin{array}{l}\text { examination questions. } \\
\text { Forging of marks. }\end{array}$ & - & 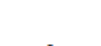 & - & - & - & - & $01(1 \%)$ & - & $01(1 \%)$ & - & Expulsion \\
\hline & Sum Total & $18(18.2 \%)$ & $17(17.2 \%)$ & $16(16.1)$ & $04(4.0 \%)$ & $13(13.1 \%)$ & $12(12.1 \%)$ & $14(14.1 \%)$ & $05(5.1 \%)$ & $61(61.6 \%)$ & $38(38.4 \%)$ & \\
\hline & Grand Total & & & & & & & 19(1 & $2 \%)$ & & $0 \%$ & \\
\hline
\end{tabular}

Source: Field work 2014.

As indicated in Table 3 above 35(35.4\%) students were recorded in 2011, 20(20.2\%) in 2012, 25(25.2\%) in 2013 and 19(19.2\%) in 2014. Dwelling on this presentation, the highest number was recorded in 2011, followed by 2013 and 2012. This result is further analyzed in a form of graph as indicated in figure ii.

Figure ii: The Number of Students Caught for Academic Dishonesty.

Source: Field work 2014

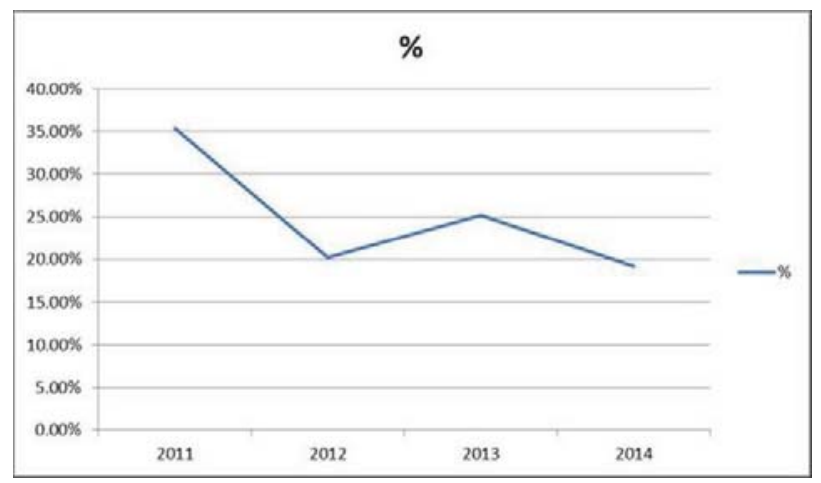

Objective iii investigated the gender of students involved in academic dishonesty. The result according to table 3 shows that male students represent the majority while their female colleagues constitute the minority. Specifically in 2011, 18 male students were caught as against 17 female. In 2012, 16 male students were involved as against 4 female. In 2013, 13 male students were involved as against 12 female and in 2014, 14 male students were caught as against 5 female folk. This is further presented in a form of histogram as indicated in figure iii below:

Figure iii: Gender Composition of Students Who Involved in Academic Dishonesty.

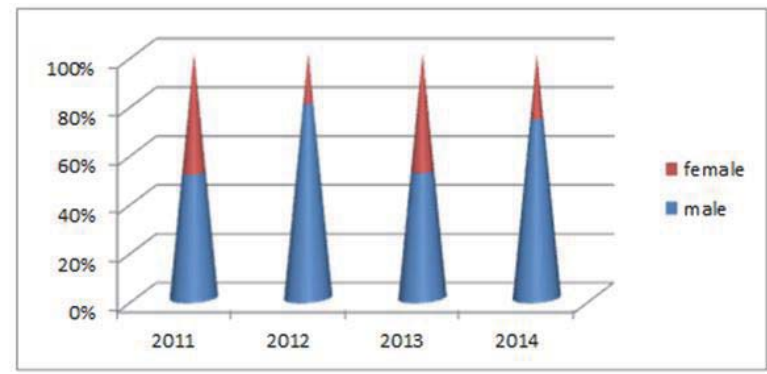

Source: Field work 2014 
Objective in investigated disciplinary actions placed on students caught for involving in academic dishonesty. The result in table 3 equally revealed that students involved were expelled from the University.

Objective v examined strategies which Student Affairs Personnel engaged to ensure academic honesty. The following ten under-listed strategies / measures were retrieved from the data provided by the Head of Student Affairs Section.

1. Passing information to students warning them against the danger of academic dishonesty.

2. Ensuring that students caught for academic dishonesty face disciplinary actions.

3. Checking students to prevent them from carrying implicating materials to the examination halls.

4. Assisting students who have moral issues by referring them to the Chaplain.

5. Encouraging students to be studious on campus instead of playing around.

6. Preaching against academic dishonesty in Chapel Services.

7. Referring students who have moral challenges to bible schools and counseling centre for rehabilitations.

8. Acting as role models to students on campus.

9. Organising programmes and lectures bothering on integrity for students from time to time.

10. Monitoring students to ensure that they comply with the rules and regulations of examinations.

Objective vi investigated the effectiveness of Student Affairs Personnel in ensuring academic honesty. The result of investigation is hereby presented below

Table 4: Opinion of Students on the Effectiveness of Student Affairs Personnel in Curtailing Academic Dishonesty.

\begin{tabular}{|c|c|c|c|c|c|c|}
\hline SN & Strategies & $\begin{array}{l}\text { Strongly } \\
\text { agree }\end{array}$ & Agree & Disagree & $\begin{array}{l}\text { Strongly } \\
\text { disagree }\end{array}$ & Total \\
\hline 1 & $\begin{array}{l}\text { Checking students to prevent them from } \\
\text { carying implicating materials to the }\end{array}$ & $57(27.9 \%)$ & $108(52.9 \%)$ & $21(10.3 \%)$ & $18(8.8 \%)$ & $204(100 \%)$ \\
\hline 2 & $\begin{array}{l}\text { Monitoring students to ensure that they } \\
\text { comply with the rules and regulations of } \\
\text { examinations }\end{array}$ & $84(41.2 \%)$ & $105(51.5 \%)$ & $10(4.9 \%)$ & $05(2.5 \%)$ & $204(100 \%)$ \\
\hline 3 & $\begin{array}{l}\text { Passing information to students waming } \\
\text { them against the danger of academic } \\
\text { dishonesty. }\end{array}$ & $84(41.2 \%)$ & $101(49.5 \%)$ & $07(3.4 \%)$ & $12(5.9 \%)$ & $204(100 \%)$ \\
\hline 4 & $\begin{array}{l}\text { Preaching against academic dishonesty } \\
\text { in Chapel Services. }\end{array}$ & $75(36.8 \%)$ & $98(48 \%)$ & $11(5.4 \%)$ & $20(8.8 \%)$ & $204(100 \%)$ \\
\hline 5 & $\begin{array}{l}\text { Ensuring that students caught for } \\
\text { academic dishonesty face disciplinary } \\
\text { actions. }\end{array}$ & $89(43.6 \%)$ & $93(45.6 \%)$ & $13(6.3 \%)$ & $09(4.5 \%)$ & $204(100 \%)$ \\
\hline 6 & $\begin{array}{l}\text { Organising programmes and lectures } \\
\text { bothering on integrity for students from } \\
\text { time to time }\end{array}$ & $40(19.6 \%)$ & $91(44.6 \%)$ & $33(16.2 \%)$ & $40(19.6 \%)$ & $204(100 \%)$ \\
\hline 7 & acouraging students to be studious. & & $86(42.2 \%)$ & $37(18.1 \%)$ & $37(18.1 \%)$ & $204(100 \%)$ \\
\hline 8 & $\begin{array}{l}\text { Assisting students who have moral } \\
\text { problem by refering them to the } \\
\text { Chaplain }\end{array}$ & $36(17.7 \%)$ & $58(28.4 \%)$ & $36(17.7 \%)$ & $74(36.3 \%)$ & $204(100 \%)$ \\
\hline 9 & $\begin{array}{l}\text { Acting as role models to students on } \\
\text { campus. }\end{array}$ & $28(13.7 \%)$ & $68(33.3 \%)$ & $41(20.1 \%)$ & $67(32.9 \%)$ & $204(100 \%)$ \\
\hline 10 & $\begin{array}{l}\text { Referning students who have moral } \\
\text { challenges to bible schools and } \\
\text { counseling centre for rehabilitations }\end{array}$ & $31(15.2 \%)$ & $61(29.9 \%)$ & $59(28.9 \%)$ & $53(25.9 \%)$ & $204(100 \%)$ \\
\hline
\end{tabular}

Source: Field work 2014.

Dwelling on table 4, 52.9\% respondents strongly agreed that Student Affairs Personnel are effective in checking students, in order to prevent them from carrying implicating materials to the examination halls. This is followed by $27.9 \%$ others, who agreed. Respondents who disagreed represent $10.3 \%$ while those who strongly disagreed constitute $8.8 \%$.

Fifty-one point five percent (51.5\%) of the entire sample agreed to the effectiveness of Student Affairs Personnel in monitoring students to ensure their compliance with the rules and regulations of examination while just $41.2 \%$ others strongly agreed. Respondents who disagreed constitute $4.9 \%$ and just $2.5 \%$ of the sample strongly disagreed.

Forty-nine point five percent (49.5\%) of the total sample agreed that Student Affairs Personnel are effective in passing information to students, warning them against the danger of academic dishonesty. Respondents who strongly agreed to that measure constitute $41.2 \%$. About $5.9 \%$ other students strongly disagreed while the rest of them (3.4\%) disagreed.

Forty-eight percent (48\%) of the sample agreed that student Affairs Personnel are effective in preaching against academic dishonesty in Chapel Services while $36.8 \%$ others strongly agreed to that. About $8.8 \%$ others strongly 
disagreed while the remaining (5.4\%) disagreed.

In respect of the strategy of enforcing disciplinary measures for students caught for academic dishonesty, $45.6 \%$ of the sample agreed that they are effective. Very close to that are respondents who strongly agreed, which represents $43.6 \%$. Respondents who disagreed constitute $6.4 \%$ while those who strongly disagreed represent $4.5 \%$.

In areas of organizing programmes and lectures on integrity for students from time to time, $44.6 \%$ of the entire sample agreed that Student Affairs Personnel are effectiveness. Respondents who agreed and those who strongly agreed represent the same percentage with $19.6 \%$ while the remaining $16.2 \%$ disagreed.

Students who agreed to the effectiveness of Student Affairs Personnel in encouraging students to be studious represent $42.2 \%$ of the total sample. About $21.6 \%$ others strongly agreed to this strategy while respondents who strongly disagreed and disagreed represent $18.1 \%$ each.

In another development, $36.3 \%$ of the sample strongly disagreed that Student Affairs Personnel are effective in assisting students who have moral challenge by referring them to the Chaplain while just $28.4 \%$ agreed that they are effective. Students who strongly agreed and those who disagreed are in the same category with $17.7 \%$.

Thirty-three point three percent (33.3\%) of respondents consented to the effectiveness of Student Affairs Personnel in acting as role models to students. This is closely followed by $32.5 \%$ respondents who strongly disagreed. Respondents who disagreed constitute $20.1 \%$ while just $13.7 \%$ of them strongly agreed.

Lastly, $29.9 \%$ of the sample agreed that Student Affairs Personnel are effective in referring students who have moral challenge to bible school and counseling center for spiritual rehabilitations, but $28.9 \%$ respondents disagreed with this. Respondents who strongly disagreed represent $16 \%$ while just $25.9 \%$ of the sample strongly agreed.

\section{Discussion}

This study aimed at addressing 6 objectives. The first objective identified categories of academic dishonesty. Nine of such categories were discovered in the process of investigation. These include the use of: calculator, mobile phone, Ipod, copying from others, copying form microchips, exchanging answer scripts, buying of question papers, leakage of examination questions and forging of marks. Previous studies validate some of these categories. For instance, the work of Kobiowu \& Alao, (2005) corroborate the finding on copying answers from microchips, while the result concurs the findings of Omonijo \& Nnedum, (2012b) on the use of I-Pod, mobile phone and calculators. Also, leakage of examination papers / buying of questions and answers prior examination corroborate with Chigozie, (2012). However, some of these categories occurred once. It therefore assumed that these categories are not common in the institution under study. Probably, the zero tolerance for academic dishonesty might have been responsible for this.

The second objective examined the number of students caught for this menace. The result indicated 99 students, out of which the highest $35.4 \%$ was recorded in 2011, followed by 25.2\% in 2013. The least was recorded in 2014 with $19.2 \%$. This is an indication that cases of academic dishonesty is coming down, but in a zigzag direction. Maybe this can be attributed to the capital punishment placed on academic dishonesty.

The third objective examined gender composition of students caught for academic dishonesty. Out of 99 students caught, $61.6 \%$ were male while just $38.4 \%$ of them were female. Although female in this sample were more than male, but the study employed information recorded from the register and not questionnaire filled by the students. However, the finding here corroborate Omonijo et al., (2011a) who found out that male students are more prone to crime than their female counterparts and negate Rotimi et al., (2014) on the same.

The fifth objective investigated disciplinary actions given to the students involved. The result indicated that they were all expelled from the University. This shows that the institution has zero tolerance for academic dishonesty and that might have been responsible for the decline in the cases of academic dishonesty in the last three years.

The second to the last objective investigated measures that Student Affairs Personnel use to curtail academic dishonesty. The result indicated 10 measures. Three of these measures: (i) ensuring that students caught for academic dishonesty are disciplined, acting as role model to students and assisting them to address their challenges concur with Nye (1958), who presents four measures for controlling deviant behaviours.

The last objective examined effectiveness of Student Affairs Personnel in ensuring academic honesty. The result indicated that Student Affairs Personnel are effective in 9 strategies out of ten (see table 4). Views of students sampled have shown that these personnel are not effective in assisting students who have moral problems by referring them to the Chaplain. Knowing morally challenged students may be difficult for student Affairs Personnel, except if the concerned students express their minds to them, but most students may not want to expose their weakness to these personnel. Besides, moral problem is one of the social-vices confronting youths and adults in Nigeria today and it has been a strong factor responsible for academic dishonesty in tertiary institutions (Omonijo et al., 2014). So, the submission of students is 
therefore not surprising. Most of the Student Affairs Personnel may even be confronted with a moral problem, which could make it difficult for them to assist students. Besides, roles of Student Affairs Personnel in monitoring students' are relatively recent in higher education in Nigeria and they are associated with only private universities. Therefore, these personnel may not be all that effective at the elementary stage of its existence.

Theoretically, the finding of this study corroborates Nye, (1958) who suggests discipline for disobedient children and the use of role models as well as attending to students needs in order to prevent them from indulging in deviant behaviours. These are parts of measures put in place to ensure academic honesty in the institution under study while the last-Reward for obedient students has not been considered as one of the measures necessary to curtail academic dishonesty.

\section{Conclusion}

This study concludes with 9 categories of academic dishonesty and ninety-nine total number of students caught, out of which male students constitute the majority while their female counterparts represent the minority. The study also concludes with expulsion as disciplinary action taken against those who involved in academic dishonesty. Moreover, the study concludes that Student Affairs Personnel use ten measures to curtail academic dishonesty, out of which they are effective in nine.

\section{Recommendations}

It is recommended that efforts should be made to introduce rewards system in the Department of Student Affairs for obedient students. When disobedient students are being punished obedient ones should equally be rewarded.

Also, efforts should be geared towards assisting students who have challenges, either financially or morally or socially by Student Affairs Personnel.

\section{References}

Adeyemi, T. O. (2010). Examination Malpractices among Secondary Schools Students in Ondo State, Nigeria: Perceived Causes and Possible Solutions. American-Eurasian Journal of Scientific Research, 5 (1): 67-75

Aina, T.A. (2010). The Role of the private University in Driving Social and economic Change:Challenges and Opportunities. 5th Convocation Ceremony's Distinguished Lecture at Covenant University, Ota: $\mathrm{p} 2$

Akinnubi, O.P and Kayode, D.J. (2012).Student Personnel Services And Students' Behaviours in University of Ilorin, Ilorin. Global Journal of Applied Sciences, Management and Social Sciences, 11(14)

Akpan, P. A. (2000). Housing Condition and Environmental Quality in Ikot, Ekpene, Nigeria.African Journal of Social and Policy Studies, 1(1) $1-7$

Alechenu, J. (2012). Nigerian universities lack enough lecturers - Report. Universities News, http://www.universitiesnews.com/ 2012/11/16/nigerian-universities-lack-enough-lecturers-report/, October 8, 2013

Amie, R and McKibban, C.A.B. (2013).Academic Dishonesty: An In-Depth Investigation of Assessing Measurable Constructs and a Call for Consistency in Scholarship. Journal of Academic Ethics, 11(3): 185-197.

Animasahun, R.A. (2014).Marital Conflict, Divorce and Single Parenthood as Predictors of Adolescent Antisocial Behaviour in Ibadan. British Journal of Education, Society and Behavioural Science, 4(5): 592-602.

Archibong, I. A. (2012). Forms of Dishonesty Amongst Academic Staff and the Way Forward. Canadian Social Science, 8(6), 39-43.

Babalola, Y.T. (2012).Awareness and Incidence of Plagiarism among Undergraduates in a Nigerian Private University. African Journal of Library, Archives and Information Science, 22(1):55

Bassey U. (2001).pupil personnel Management in school; a new Emphasis Under the UBE Scheme. Ahmadu Bello University Journal of Education, legal and Management Studies, 3(2)

Billingsley, M.P. (2014). Prairie View A and M University, 2014. Accessed on February 9.Available on http://www.pvamu.edu/sa/letterfrom-miron-p-billingsleyl

Brimble M and Stevenson-Clarke, P, (2005).Perceptions of the prevalence and seriousness of academic dishonesty in Australian universities. The Australian Educational Researcher

Chigozie (2012). UNN Cancels Post-UTME Test Over Leakage of Question Papers. Available on <http://www.informationng.com /2012/06/unn-cancels-post-utme-test-over-leakage-of-question-papers.html>

Covenant University (2014). Student Handbook. Ota: Dominion Printing Press.

Denga, D and Denga H. (1998). Educational Malpractices and Cultism in Nigeria. Calabar: Rapid Education Publishers, 1998

Dike, V.E. (2014). Corruption in Nigeria: A New Paradigm for Effective Control, 2008. Accessed on Feb. 8 2014. Available on www.AfricaEconomicAnalysis.orghttp://www.africa.org/articles/gen/corruptiondikehtm.html

Drinkworth, A. (2014). Positive \& Negative Influences of Parents on Their Children. Global Post, America World News site. 2014 
http://everydaylife.globalpost.com/positive-negative-influences-parents-children-6070.html

Edewor, P.A. (2014). Homeless Children and Youths in Lagos, Nigeria: Their Characteristics, Street Life and Sexual Behaviour. Mediterranean Journal of Social Sciences; 5(1):537-545

Eastman, J. K, Reisenwitz, T. H and Iyer, R. (2008). The Impact of Unethical Reasoning On Different Types Of Academic Dishonesty: An Exploratory Study. Journal of College Teaching \& Learning, 5(12) 7-16

Fawkner M and Keremidchieva, G. (2004). Plagiarism, Cheating and Academic Dishonesty-Have you Been there? Information and Security: An International Journal, 14 113-137

Friedman, H.W., \& Schustack, M.W. (2011). Personality: Classics theories and modern research. (5th Edition). Boston, MA: Allyn \& Bacon

Freud, S. (1940). An Outline of Psychoanalysis. Standard Edition 23, pp. 189-192.

Gallegos, D. (2014). Should You Pay a Kid for Getting Good Grades? The Wall Street Journal . Available on <http://online.wsj.com/news/articles/SB1000142412788732340710457903693 1930916274

Higgins, A and Clark, F.P. (1991). Lawrence Kohlberg's Approach to Moral Education. Columbia: University Press.

Igwe, C.N. (2011). Socio-economic Developments and the Rise of 419 Advanced-Fee Fraud in Nigeria. European Journal of Social Sciences, 20 (1):184-193.

Iheanacho, S.B.C., Ikpeme, E.E and Saba, I.A. (2013).An assessment on provision of recreational facilities in Nigerian Universities in the 21st century. Journal of Public Administration and Governance,3(1): 95-101.

Jean-Marie, H.Q. (2012). The Root Cause of Widespread corruption In Sub-Saharan Post-Colonial Nation-States. Asian Horizons, 6(1): 103-108

Johnson, O.O. (1998).The role of guidance counselor in curbing students' unrest in Nigerian University campuses. Guidance \& Counseling, 21, (1), 93-100

Kenneth, J.S., Jeanette, A.D and Debbie, E. (2004).An Examination of Cheating and its Antecedents Among Marketing and Management Majors", Journal of Business Ethics, 50(1): 66.

Kobiowu, S. V. and Alao, F. (2005) The Challenges of Examination Management in the Developing Societies: The Nigerian Scenario. International Journal of African \& African American Studies, iv(2): 39-47.

Maurer, R. (2013). Corporate Fraud on the Rise Worldwide. Accessed on March 14, 2014.Available on http://www.shrm.org/ hrdisciplines/global/Articles/Pages/Corporate-Fraud-Rise-Worldwide.aspx

Minot, N. (2011). Contract Farming in sub-Saharan Africa: Opportunities and Challenges Prepared for the policy seminar: Smallholderled Agricultural Commercialization and Poverty Reduction: How to Achieve It? 18-22 April 2011, Kigali, Rwanda.

Morrison S. (2013) Nate Thayer accused of plagiarism [UPDATED]. Colombia Journalism Review. Accessed on February 27, 2014. Available on < http://www.cjr.org/the_kicker/nate_thayer_accused_of_plagiar.php>

Musari, A. (2013). Nigerian Jailed in U.S. Over N1.8b Fraud. Guardian, Daily. September 12:7

Nadelson, S. (2007). Academic misconduct by university students: Faculty perceptions and-responses. Plagiary: Cross-Disciplinary Studies in Plagiarism, Fabrication, and Falsification, 2(2):1-10.[Online]Available:quod.lib.umich.edu/cgi/p/pod/dod-idx?c=plag; idno $=5240451 \ldots$

Nnodim, O. (2013). Nigeria's unemployment rate rises to 23.9\% -NPC. Punch, Daily. Oct.11th.

Nnonyelu, A.N, Uzoh B and Anigbogu K. (2013). No Light At The End Of The Tunnel: Corruption And Insecurity In Nigeria. Arabian Journal of Business and Management Review, 2(6): 182-193.

Nye, F.I. (1958). Family Relationships and Delinquent Behavior. New York: John Wiley.

Odia, L.O \& Omofonmwan, S.I. (2007).Educational System in Nigeria Problems and Prospects. Journal of Social Sciences, Kamla-Raj Enterprises,14(1): 81-86

Oluyeba, N. F. (1998). Examination Malpractice: A recurring Decimal in Educational Assessment in Nigeria. A book of Readings on Issues on Examination Malpractices in Nigeria. Ado-Ekiti: PETOA Educational Publishers

Omonijo, D.O. (1995). Juvenile Delinquency; Ado-Ekiti Secondary Schools as Case Study; Causes and Solutions. An Unpublished B.Sc Project. Faculty of The Social Sciences, Ondo-State University, Ado-Ekiti. Ekiti-State.

Omonijo, D.O \& Fadugba, O.A. (2011). Parental Influence on Wards in Escalation of Examination Misconduct in Nigeria. European Journal of Social Sciences, 19 (2): 297- 307.

Omonijo, D. O., Nndeum, O. O. U., Ezeokana, J. O. (2011a). Youthful Lust and Violation of Mobile Phone Rule in a Private Christian Mission University, South West Nigeria. World Journal of Education; 1(2): 49-61. Available on http://www.sciedu.cal journal/index.php/wje/article/view/456/224

Omonijo, D.O., Nnedum, O.A.U., Ezeokana, J.O. (2011b).Understanding the Escalation of brain drain in Nigeria from poor leadership point of view. Mediterranean Journal of Social Sciences, (2)3:487-510.

Oniye, A.O and Alawaye, A.S. (2008).Female Students Perceived Causes of and Solution to Examination Malpractice in Asa Local Government: Implication For Counselling, Sokoto Educational Review, 10(2)

Onyidoh, H. (2008). The decline of the education system in Nigeria Retrieved from Google Search http://www.helium.com/items/525840the-decline-of-the-education-system-in- nigeria October 7, 2013.

Otokunefor, T. (2011).Why Nigerian Universities Produce Poor Quality Graduates. Alpha Education Foundation Educational Monograph Series No. 3: 1-22.

Premium Times. (2014). University of Calabar defends sack of lecturers for academic fraud. Accessed on February 27, 2014. Available on < http://premiumtimesng.com/news/133321-university-of-calabar-defends-sack-of-lecturers-for-academic-fraud.html> 
Rittman, A.L. (1996). Academic Dishonesty Among College Students. Journal of Personality and Social Psychology, 15, 48-56.

Rhatigan, J.J. (2000). The Handbook of Student Affairs Administration, The History and Philosophy of Student Affairs (2 ed.). San Francisco, CA: Jossey-Bass. pp. 3-13.

Rotimi, O.A., Omonijo, D.O and Uche, O.O.C. (2014). Influence of Personality Types and Socio-Demographic Characteristics of Students on Examination Malpractice: Case of Secondary Schools in Ibadan. European Journal of Scientific Research, 124(4), 486-499.

Russel, R. (1994) Confidentiality in Examinations. Paper presented at the AEAA 12thAnnual Conference on Challenges of Educational Assessment in Africa.

Silberman, E. (2012). "Review of Psychodynamic Therapy: A Guide to Evidence-Based Practice." Psychiatry: Interpersonal and Biological Processes 75.3: 298-301. Psyc INFO.Web.

Soap, M.Q and Dogitimiye, M. (2013). Corrupt Academic Practices: A Tragedy in Nigerian Educational System. Journal of Education and Practice, 4(27): 117-125.

Saridakisa, G and Spenglerb, H. (2012). Crime, deterrence and unemployment in Greece: A panel data approach. The Social Science Journal (Elsevier), 49, 167-174

Tabary, Z. (2014). Fraud on the rise. The Economist. Accessed on March 14, 2014.Available on http://www.economistinsights.com/ business-strategy/opinion/fraud-rise-0

Theron, P.M. (2013), 'Corruption in Sub-Saharan Africa: A practical-theological response', Indie Skriflig/In Luce Verbi 47(1), Art. \#676, 8 pages. Available on <http://dx.doi.org/ 10.4102/ids. 47i1.676>

Ungar, R. (2014). Governor Scott Walker Caught In Political Plagiarism. Accessed on Feb. 27, 2014. Available on < http://www.forbes. com/sites/rickungar/2011/04/25/governor-scott-walker-caught-in-political-plagiarism/>

Uzokwe, A.O. (2008). Prostitution In Nigerian University Campuses (Part I). Nigeria World. Accessed on Feb. 2014. Available on http://nigeriaworld.com/columnist/uzokwe /072108.html

Vivian, M. (2012). Four Nigerian University Students Burnt Alive For Stealing Phones And Laptops - Video - Accessed on http://www.africangrio.com/headlines/190431-four-nigerian-university-students-burnt-alive-for-stealing-phones-and-laptopsvideo.html. 